\title{
RESPONSE SURFACE OPTIMIZATION OF LYOPROTECTANT FROM AMINO ACIDS AND SALTS FOR BIFIDOBACTERIUM BIFIDUM DURING VACUUM FREEZE-DRYING
}

\author{
- Research paper - \\ Kangru QI*, He CHEN*1, Hongchang WAN**, Man HU*, Yuxi WU* \\ * School of Food and Biological Engineering, Shaanxi University of Science \& Technology, \\ Xi'an, 710021, China \\ **Shaanxi Yatai Dairy Co., Ltd., Xianyang, 713701, China
}

\begin{abstract}
High quality probiotic powder can lay the foundation for the commercial production of functional dairy products. The freeze-drying method was used for the preservation of microorganisms, having a deleterious effect on the microorganisms viability. In order to reduce the damage to probiotics and to improve the survival rate of probiotics during freeze-drying, the Response Surface Methodology (RSM) was adopted in this research to optimize lyoprotectant composed of amino acids (glycine, arginine) and salts $\left(\mathrm{NaHCO}_{3}\right.$ and ascorbic acid). Probiotic used was Bifidobacterium bifidum BB01. The regression model $(\mathrm{p}<0.05)$ was obtained by BoxBehnken experiment design, indicating this model can evaluate the freeze-drying survival rate of $B$. bifidum BB01 under different lyoprotectants. The results indicated these concentrations as optimal (in W/V): glycine $4.5 \%$, arginine $5.5 \%, \mathrm{NaHCO}_{3} 0.8 \%$ and ascorbic acid $2.3 \%$, respectively. Under these optimal conditions, the survival rate of lyophilized powder of B. bifidum BB01 was significantly increased by $80.9 \%$ compared to the control group $(6.9 \pm 0.62 \%)$, the results were agreement with the model prediction value $(88.7 \%)$.
\end{abstract}

Keywords: Bifidobacterium bifidum, amino acids and salts, freeze-drying, lyoprotectants, optimization

\section{INTRODUCTION}

Probiotics are living microorganisms, which can confer a health benefit to the host (WHO, 2001). Therefore, probiotics are more and more widely added to food for human beings health. Meanwhile, the research and application of probiotics have gained much attention, such as the United States, Germany, Japan, Russia, etc.

Most commonly, probiotics are mainly added to dairy products, such as fermented milk, yoghurt, cheese ice cream and fruit juice (Fritzenfreire et al., 2010; Ramchandran \& Shah., 2010; Ranadheera et al., 2010). Fruit juices have the better advantage that suitable for people with lactose intolerance. Freezedrying method has been widely used in microbiology for many decades to stabilize and store cultures (Santivarangkna et al., 2007). However, the numbers of viable bifidobacterium bifidum reduce rapidly owing to the bactericidal effects of the low $\mathrm{pH}$, temperature (Sun \& Griffiths., 2000), oxygen and limiting nutrient conditions during freeze- drying process and storage (Ji \& Guo., 2008). Microorganisms vary greatly in their tolerance to freeze-drying and the addition of lyoprotectant can reduce cell death. It is neccessary to optimize lyoprotectant formula for obtaining the maximum viability and stability of strains (Morgan \& Vesey., 2009). More and more lyoprotactants of bifidbacteria have been reported. Research found that carbohydrates have a protective effect on probiotics (Ljm et al., 1997). Carbohydrates as a protective agent increases the stability of cellular protein by forming hydrogen bonds, thus reducing the risk of exposure to stressful conditions (Champagne et al., 1991). Some studies also indicated that some salt buffer solutions such as sodium chloride or potassium chloride, sodium citrate, phosphate(Kurtmann et al., 2009; Ohtake et al., 2004), protect cells from injury during the freeze drying process. The mechanism of cell damage in the freezing process has been studied for decades, currently, considered to be mainly by solute effects and mechanical effects (Crowe et al., 2002). The loss of bacteria cell viability is

\footnotetext{
${ }^{1}$ Corresponding author. E-Mail address: chenhe419@gmail.com
} 
mainly due to hostile environmental conditions such as ice crystallization and high osmotic pressure (Yang et al., 2012). Low temperature and water evaporation will cause a lot of damages to the bacteria during freeze drying process, the number of living bacteria will be greatly decreased when the direct freezing of the liquid. Removal of water during freezedrying may cause structural integrity of these cell components to be unstable, resulting in loss or impairment of function (Leslie et al., 1995). Besids, sample surface is easy to dehydrate faster which causes sample local dry, thus leads to biological macromolecules material protection layer destruction (Iaconelli et al., 2015).

Significant improvement survival of probiotics during freeze-drying has been found in the research of whey protein (Weinbreck et al., 2009). High survival of probiotic bacteria in skim milk as protectants have been demonstrated (Thomas et al., 2009). Besides, proteins, sugars and their interaction had significant effects on acid tolerance, bile tolerance and maintenance of $\beta$-aminoglutaric acid, lactic dehydrogenase (LDH) and adenosine triphosphatase (ATP) activities (Dianawati et al., 2013). Poly vinyl pyrrolidone (PVP) and bovine serum albumin (BSA) can also protect the bacteria from the freezing and drying process (Liu \& Meng., 2006). Mechanisms of protective agent are not similar, some protective agents as fillers or as an anti-freeze, antioxidant, $\mathrm{pH}$ regulator, buffer etc. Generally, interaction of various agents showed better effects during freezedrying. Therefore, several protectants are mixed together according to a certain formula for a better performance (Wang, 2000).

\section{MATERIALS AND METHODS}

Microrganism culture and preparation of lyoprotectants: Bifidobacterium bifidum BB01 was preserved by school of Food and Biological Engineering, Shaanxi University of Science \& Technology. B. bifidum BB01 was grown in MRS medium with 5\% (v:v) inoculum at $37{ }^{\circ} \mathrm{C}$ for $16-18 \mathrm{~h}$. Bifidobacteria activates three generations and centrifugates at $8000 \mathrm{rpm}$ for $20 \mathrm{~min}$. After wet cell mixs with different lyoprotectants solution at a ratio of $1: 1(\mathrm{~W} / \mathrm{V})$, pre-frozen at $-20{ }^{\circ} \mathrm{C}$ for $12 \mathrm{~h}$ and freeze-drying $\left(-51^{\circ} \mathrm{C}\right)$ for $24 \mathrm{~h}$.
Amino acid is one of the most common protein lyoprotectants during vacuum freeze drying, in the freezing process, the low concentration of glycine can inhibit the protein denaturation by inhibiting the change of $\mathrm{pH}$ value (Mattern et al., 1999). Ascorbic acid as a reducing agent sometimes to the freezing and drying processes of the protein also played a protective role because of anaerobic characteristic of $B$. Bifidum BB01, which could lower the oxidation-reduction potential and consume the oxygen in experiment (Carpenter et al., 1997). In some freeze dried products, adding salt and amine can obtain the stable effect of freeze drying, $\mathrm{NaHCO}_{3}$ as a buffering agent can effectively reduce the damage caused by the dehydration of the cells. Besides, glycine, arginine, $\mathrm{NaHCO}_{3}$ and ascorbic acid can cooperate to protect the cell during vacuum freeze drying.

The development of probiotic lyoprotectants become the focus in relevant reasearch (Saadatzadeh et al. 2013; Tripathi \& Giri. 2014). Generally, each probiotic have its own lyoprotectants, the Response surface analysis is also an optimization method, which is the use of graphics technology to show a function of relations, so that we rely on intuitive observation to select the optimal formula of lyoprotectants for probiotic in the design. In our previous work, glycine, arginine, $\mathrm{NaHCO}_{3}$ and ascorbic acid were screened from amino acids and salts as lyoprotectants on B. bifidum BB01 during freeze-drying by single factor experiment and Plackett-Burman experiment (Chen et al., 2014; Chen et al., 2013). Based on the results above, RSM is adopted in this research to optimize lyoprotectants formula of B. bifidum BB01 during freeze-drying.

Treatment of lyoprotectants: All the lyoprotectants used in the experiment were dissolved in distilled water and formulated into various concentrations.

Vacuum freeze-drying: The cells were prefrozen at $-20{ }^{\circ} \mathrm{C}$ for $12 \mathrm{~h}$ after protective agents were added and then frozen at $-51^{\circ} \mathrm{C}$, 6.93Pa for $24 \mathrm{~h}$ by using a vacuum freeze dryer. Calculation of survival rate:

Survival rate $(\%)=\mathrm{N} / \mathrm{N}_{0} \times 100 \%$

where $\mathrm{N}$ and $\mathrm{N}_{0}$ represent the viable counts (cfu/g ) after freeze-drying and the initial count (cfu/g) before freeze-drying. The viable count method is as follows, the frozen 
concentrate is diluted 10 times in the PBS buffer. The total number of viable bacteria is calculated by the method of plate counting, 48 $\mathrm{h}$ anaerobic incubation.

Statistical analysis of the data: SAS software was used for experiment design and regression analysis. Three-dimensional surface plots and Pareto charts were constructed by using SAS.

Box-Behnken experiment design: The significant factors (arginine, glycine, $\mathrm{NaHCO}_{3}$, ascorbic acid) were obtained from PB design. The single factor experiment results showed that the concentration of single protective agent of B. bifidum BB01 during freeze- drying was with $4-6 \%(\mathrm{w} / \mathrm{v})$ arginine, $3-5 \%$ $(\mathrm{w} / \mathrm{v})$ glycine, $0.6-1 \%(\mathrm{w} / \mathrm{v}) \mathrm{NaHCO}_{3}, 2-2.6 \%$ (w/v) ascorbic acid, and the maximum survival rate was $44.23,44.02 \%, 47.92 \%$, $36.38 \%$, respectively. And then according to the results of ascent experiment to determine the range of factors for Box-Behnken design (BBD). The lyoprotectant composition was further optimized using a four-factor, threelevel (BBD) and three levels of $\mathrm{N}=27$ test with the Y (freeze-dried survival rate of B. bifidum BB01) as response value. Factors encoding table are shown in Table 1.

Table 1. Experimental factor levels of Box-Behnken design

\begin{tabular}{|c|c|c|c|c|}
\hline factors/ level & $\mathrm{X} 1$ arginine $(\%)$ & $\mathrm{X} 2$ glycine $(\%)$ & X3 $\mathrm{NaHCO}_{3}(\%)$ & $\mathrm{X} 4$ ascorbic acid (\%) \\
\hline-1 & 5 & 4 & 0.75 & 2.4 \\
\hline 0 & 5.5 & 4.5 & 0.8 & 2.3 \\
\hline 1 & 6 & 5 & 0.85 & 2.2 \\
\hline
\end{tabular}

Note: \% indicates the mass concentration of each substance, $\mathrm{g} / 100 \mathrm{ml}$.

A polynomial equation was used as follows:

$\mathrm{Y}=\mathrm{a}_{0}+\mathrm{a}_{1} \mathrm{X} 1+\mathrm{a}_{2} \mathrm{X} 2+\mathrm{a}_{3} \mathrm{X} 3+\mathrm{a} 4 \mathrm{X} 4+\mathrm{a}_{12} \mathrm{X} 1 \mathrm{X} 2+\mathrm{a}_{13} \mathrm{X} 1 \mathrm{X} 3+\mathrm{a}_{14} \mathrm{X} 1 \mathrm{X} 4+\mathrm{a}_{23} \mathrm{X} 2 \mathrm{X} 3+\mathrm{a}_{24}$

$\mathrm{X} 2 \mathrm{X} 4+\mathrm{a}_{34} \mathrm{X} 3 \mathrm{X} 4+\mathrm{a}_{11} \mathrm{X} 1 \mathrm{X} 1+\mathrm{a}_{22} \mathrm{X} 2 \mathrm{X} 2+\mathrm{a}_{33} \mathrm{X} 3 \mathrm{X} 3+\mathrm{a}_{44} \mathrm{X} 4 \mathrm{X} 4$

In the equation (2), $\mathrm{Y}$ is the predicted responses of the dependent variable, X1, X2 $\mathrm{X} 3$ and $\mathrm{X} 4$ are the values of significant variables, $\mathrm{a}_{0}$ is the second-order reaction

\section{RESULTS AND DISCUSSIONS}

\section{RSM optimization of formulation of lyoprotectant}

RSM was used to optimize the formula of lyoprotectants. The experiment design and results are shown in Table 2, response value Y1 with a decimal representation, which indicates the survival rate of freeze-drying constant, $a_{1}, a_{2} a_{3}$ and $a_{4}$ are the linear coefficients, $a_{12}, a_{13}, a_{14} a_{23} a_{24}$ and $a_{34}$ are the interaction coefficients and $\mathrm{a}_{11}, \mathrm{a}_{22}, \mathrm{a}_{33}$ and $\mathrm{a}_{44}$ are the quadratic coefficients.

$$
\begin{aligned}
\mathrm{Y} 1= & 0.8880-0.0641 \times \mathrm{X} 1+0.0225 \times \mathrm{X} 2+0.0159 \times \mathrm{X} 3-0.0455 \times \mathrm{X} 4-0.0990 \times \mathrm{X} 1 \times \mathrm{X} 1- \\
& 0.0592 \times \mathrm{X} 1 \times \mathrm{X} 2-0.0020 \times \mathrm{X} 1 \times \mathrm{X} 3+0.0797 \times \mathrm{X} 1 \times \mathrm{X} 4-0.0767 \times \mathrm{X} 2 \times \mathrm{X} 2-0.0934 \times \mathrm{X} 2 \times \mathrm{X} 3+ \\
& 0.0761 \times \mathrm{X} 2 \times \times \mathrm{X} 4-0.1644 \times \mathrm{X} 3 \times \mathrm{X} 3+0.1012 \times \mathrm{X} 3 \times \mathrm{X} 4-0.1678 \times \mathrm{X} 4 \times \mathrm{X} 4
\end{aligned}
$$

Variance analysis and coefficient significance test of the regression equations were obtained by SAS software. The results are shown in Table 3. Analysis of variance (ANOVA) is used to evaluate the adequacy of the fitted model and test the significance of the coefficient. From Table 3, variance analysis showed that the regression equation mode is significant $(\mathrm{P}<0.05)$. powder. According to the test results of Table 2 , the regression model (equation) obtained by using SAS software is Eq.3. In the equation (3), Y1 is the predicted value of survival rate vacuum freeze-dring $B$. bifidum BB01 cells. $\mathrm{X} 1, \mathrm{X} 2, \mathrm{X} 3$ and $\mathrm{X} 4$ were arginine, glycine, $\mathrm{NaHCO}_{3}$ and ascorbic acid encoding value. 
Table 2. Design and results of Box-Behnken design $(\mathrm{N}=27)$

\begin{tabular}{cccccc}
\hline RUN & \multicolumn{1}{c}{ X1 } & X2 & X3 & X4 & Y1 \\
\hline 1 & -1 & -1 & 0 & 0 & 0.69 \\
2 & -1 & 1 & 0 & 0 & 0.72 \\
3 & 1 & -1 & 0 & 0 & 0.71 \\
4 & 1 & 1 & 0 & 0 & 0.51 \\
5 & 0 & 0 & -1 & -1 & 0.61 \\
6 & 0 & 0 & -1 & 1 & 0.28 \\
7 & 0 & 0 & 1 & -1 & 0.52 \\
8 & 0 & 0 & 1 & 1 & 0.59 \\
9 & -1 & 0 & 0 & -1 & 0.83 \\
10 & -1 & 0 & 0 & 1 & 0.59 \\
11 & 1 & 0 & 0 & -1 & 0.48 \\
12 & 1 & 0 & 0 & 1 & 0.56 \\
13 & 0 & -1 & -1 & 0 & 0.46 \\
14 & 0 & -1 & 1 & 0 & 0.64 \\
15 & 0 & 1 & -1 & 0 & 0.82 \\
16 & 0 & 1 & 1 & 0 & 0.64 \\
17 & -1 & 0 & -1 & 0 & 0.74 \\
18 & -1 & 0 & 1 & 0 & 0.73 \\
19 & 1 & 0 & -1 & 0 & 0.65 \\
20 & 1 & 0 & 1 & 0 & 0.63 \\
21 & 0 & -1 & 0 & -1 & 0.79 \\
22 & 0 & -1 & 0 & 1 & 0.58 \\
23 & 0 & 1 & 0 & -1 & 0.68 \\
24 & 0 & 1 & 0 & 1 & 0.78 \\
25 & 0 & 0 & 0 & 0 & 0.89 \\
26 & 0 & 0 & 0 & 0 & 0.89 \\
27 & 0 & 0 & 0 & 0 & 0.89 \\
\hline
\end{tabular}

Table 3. The ANOVA of Box-Behnken design

\begin{tabular}{ccccccc}
\hline SOURCE & DF & SS & MS & F & P & Sig. \\
\hline $\mathrm{X} 1$ & 1 & 0.0494 & 0.0494 & 5.2860 & 0.0403 & $*$ \\
$\mathrm{X} 2$ & 1 & 0.0061 & 0.0061 & 0.6512 & 0.4354 & \\
$\mathrm{X} 3$ & 1 & 0.0030 & 0.0030 & 0.3259 & 0.5786 & \\
$\mathrm{X} 4$ & 1 & 0.0248 & 0.0248 & 2.6544 & 0.1292 & $*$ \\
$\mathrm{X} 1 * \mathrm{X} 1$ & 1 & 0.0523 & 0.0523 & 5.5996 & 0.0356 & $* *$ \\
$\mathrm{X} 1 * \mathrm{X} 2$ & 1 & 0.0140 & 0.0140 & 14.9940 & 0.0043 & \\
$\mathrm{X} 1 * \mathrm{X} 3$ & 1 & 0.0000 & 0.0000 & 0.0018 & 0.9672 & \\
$\mathrm{X} 1 * \mathrm{X} 4$ & 1 & 0.0254 & 0.0254 & 2.7222 & 0.1249 & \\
$\mathrm{X} 2 * \mathrm{X} 2$ & 1 & 0.0314 & 0.0314 & 3.3624 & 0.0916 & \\
$\mathrm{X} 2 * \mathrm{X} 3$ & 1 & 0.0349 & 0.0349 & 11.7395 & 0.0077 & $* *$ \\
$\mathrm{X} 2 * \mathrm{X} 4$ & 1 & 0.0023 & 0.0023 & 18.4836 & 0.0019 & $* *$ \\
$\mathrm{X} 3 * \mathrm{X} 3$ & 1 & 0.1441 & 0.1441 & 15.4258 & 0.0020 & $* *$ \\
$\mathrm{X} 3 * \mathrm{X} 4$ & 1 & 0.0400 & 0.0400 & 4.2831 & 0.0607 & \\
$\mathrm{X} 4 * \mathrm{X} 4$ & 1 & 0.1502 & 0.1502 & 16.0780 & 0.0017 & $* *$ \\
model & 14 & 0.0444 & 0.0032 & 8.3941 & 0.0042 & $*$ \\
linear & 4 & 0.0833 & 0.0208 & 2.2294 & 0.1268 & $* *$ \\
quadratic & 4 & 0.0223 & 0.0557 & 5.9675 & 0.0070 & \\
cross-product & 6 & 0.0138 & 0.0229 & 6.4549 & 0.0575 & \\
error & 12 & 0.1121 & 0.0093 & & & \\
lack of fit & 10 & 0.0001 & 0.0001 & 0.2422 & 0.9712 & \\
pure error & 2 & 0.0000 & 0.0000 & & & \\
total & 26 & 0.5558 & & & & \\
\hline
\end{tabular}

Note: $* * * \mathrm{P}<0.001$, extremely significant; $* * \mathrm{P}<0.01$, highly significant; $* \mathrm{P}<0.05$, significant. 
The first-order item of the equation is not high and the cross product has certain significance, it shows that the relationship between the response value and the test factors are a simple linear relationship. The cross product $\mathrm{F}$ value is large, which indicates that there is a certain interaction among various factors. However, lack of fit is not significant, indicating that the equations are well suited for adjust experiment and experimental error are small, therefore, this regression equation can be used for predicating survival rate during freeze-drying. According to Figure 1, the response value of $\mathrm{Y} 1$ varies with the concentration of each factor. $\mathrm{X} 3 * \mathrm{X} 3$ and $\mathrm{X} 4 * \mathrm{X} 4$ are significant $(\mathrm{P}<0.05)$ effect for survival rate of bacteria, and the survival rate of freeze-dried $\mathrm{Y} 1$ is significant affected by $\mathrm{X} 3$ and $\mathrm{X} 4$. Maximum value are obtained at the turning point. The value of $\mathrm{Y} 1$ becomes higher with increase of $\mathrm{X} 3$ and $\mathrm{X} 4$, then reach the maximum value at the center point and then Y1 decreases gradually with the increase of concentration. Similarly, X1 and $\mathrm{X} 2$ also have the same impact on Y1, but the bending effect is not significant. This may be attributed to the initial addition of amino acids and salts too little cannot completely replace the loss of water molecules around the cell, when the amount is too high, which will produce osmotic pressure to cause rapid cell dehydration lead to damage to cell structure.

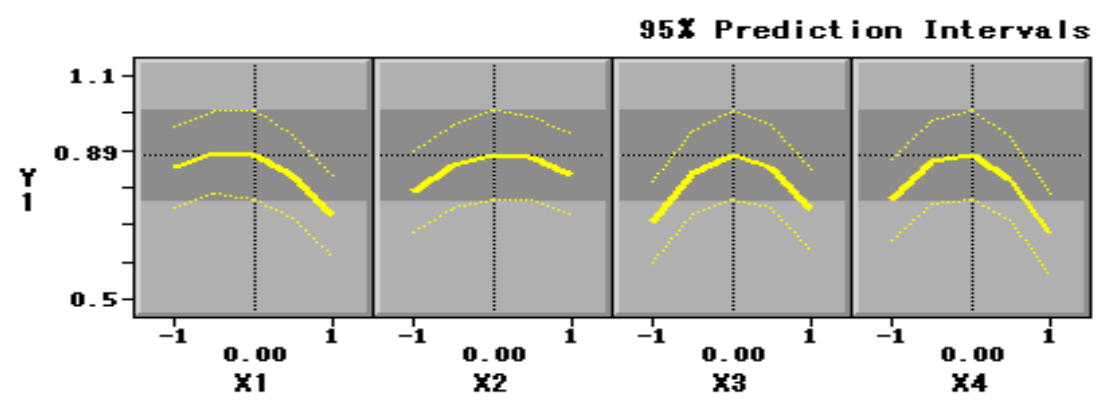

Figure 1. The trends of $\mathrm{Y} 1$ with factors

Based on the above results, response surface and contour are shown in Figures 2 - 7. From Figure 2 to 7 contour shapes, it can be known that the interaction of $\mathrm{X} 1$ and $\mathrm{X} 3, \mathrm{X} 1$ and $\mathrm{X} 4$, $\mathrm{X} 2$ and $\mathrm{X} 4$ are not obvious, but $\mathrm{X} 1$ and $\mathrm{X} 2$, $\mathrm{X} 2$ and $\mathrm{X} 3, \mathrm{X} 2$ and $\mathrm{X} 4$ have a significant cross effect. Based on the generated regression equation, we calculate partial derivative for $\mathrm{X} 1$, $\mathrm{X} 2, \mathrm{X} 3$ and $\mathrm{X} 4$ respectively, and the maximum point are also calculated. Under condition of glycine, $4.5 \%(\mathrm{~W} / \mathrm{V})$, arginine $5.5 \%(\mathrm{~W} / \mathrm{V})$, $\mathrm{NaHCO}_{3} 0.8 \%(\mathrm{~W} / \mathrm{V})$ and ascorbic acid $2.3 \%$ $(\mathrm{W} / \mathrm{V})$, predicted freeze-dried survival rate of B. bifidum BB01 is $88.7 \%$.
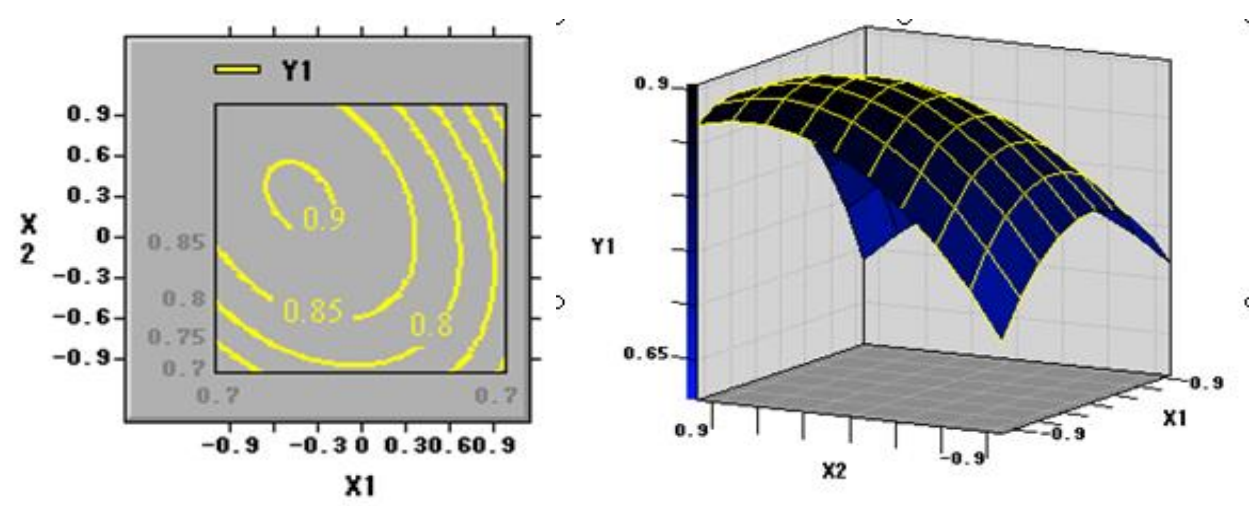

Figure 2. Response surface and contour plots of arginine (X1), glycine (X2) to survival rate of $B$. bifidum BB01 (Y1) 

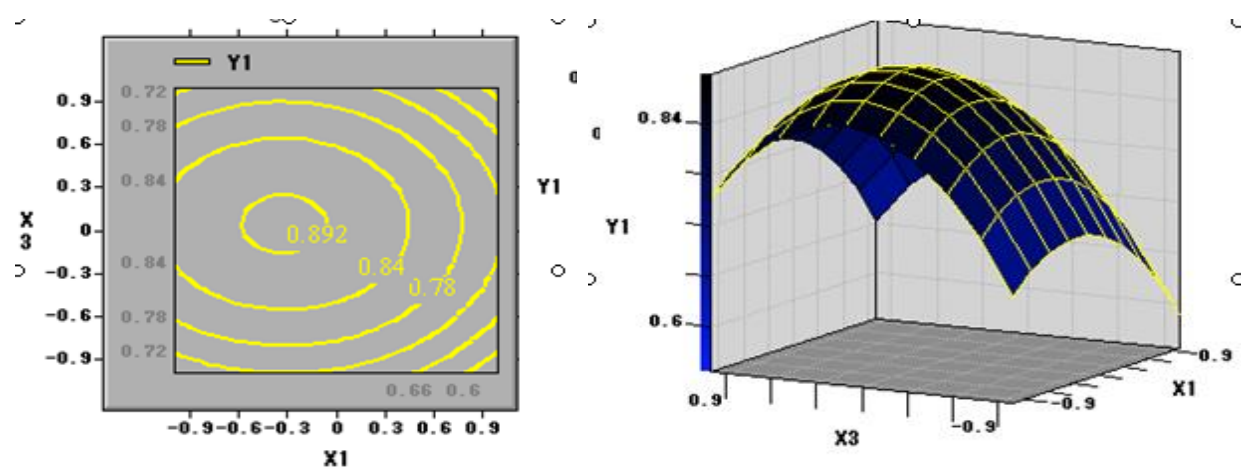

Figure 3. Response surface and contour plots of arginine (X1), $\mathrm{NaHCO}_{3}(\mathrm{X} 3)$ to survival rate of $B$. bifidum BB01 (Y1)
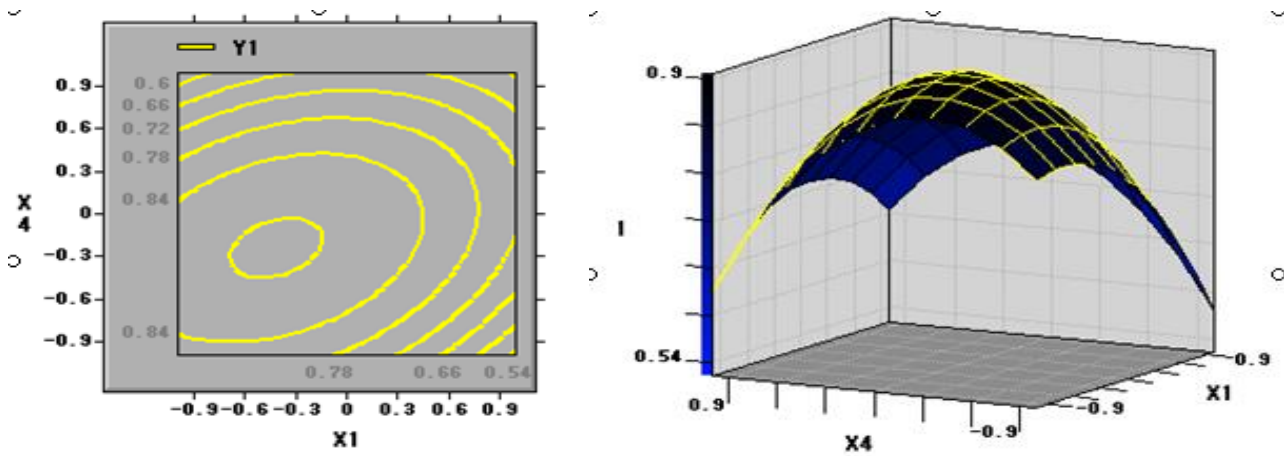

Figure 4. Response surface and contour plots of arginine (X1), ascorbic acid (X4) to survival rate of B. bifidum BB01 (Y1)
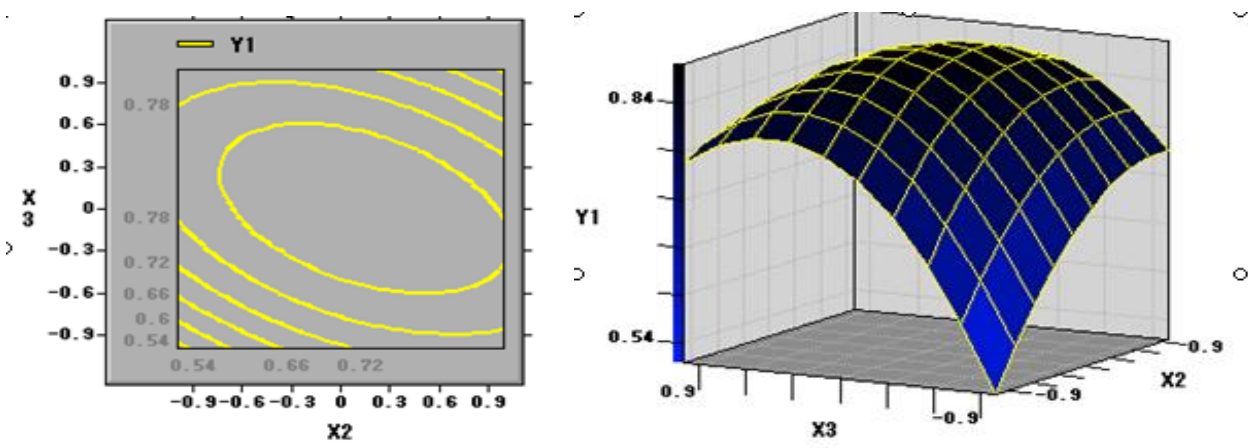

Figure 5. Response surface and contour plots of glycine (X2), $\mathrm{NaHCO}_{3}(\mathrm{X} 3)$ to survival rate of $B$. bifidum BB01 (Y1)
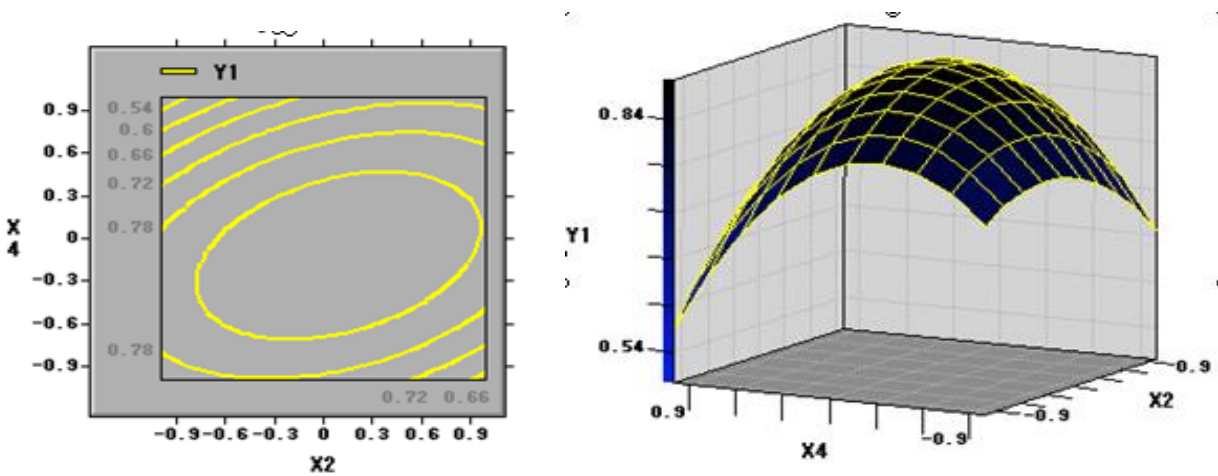

Figure 6. Response surface and contour plots of glycine (X2), ascorbic acid (X4) to survival rate of $B$. bifidum BB01 (Y1) 

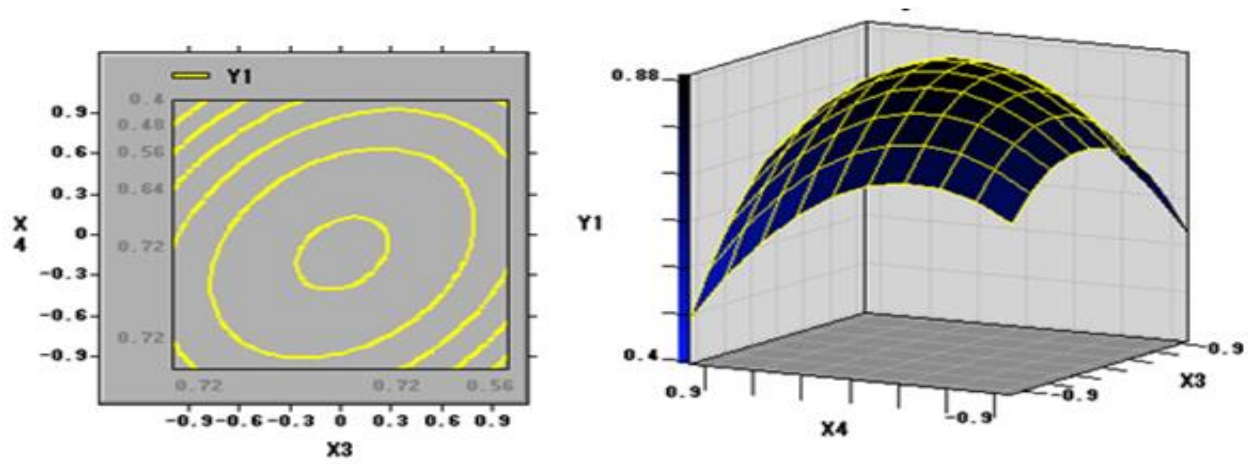

Figure 7. Response surface and contour plots of $\mathrm{NaHCO}_{3}(\mathrm{X} 3)$, ascorbic acid (X4) to survival rate of B. bifidum $\mathrm{BB} 01$ ( $\mathrm{Y} 1$ )

Verification test: In this work, control group without adding other substances and the experimental group with the lyoprotectants of amino acids and salts were conducted, the survival rate is calculated by 3 times repeated freeze drying tests, which repeated tests with $5 \%$ of inoculum size culture at $37{ }^{\circ} \mathrm{C}$ for $18 \mathrm{~h}$

\section{CONCLUSIONS}

Lyoprotectant contents for B. bifidum BB01 was optimized by Box-Behnken experiment design. The lyophilized survival rate of $B$. bifidum BB01 had the highest value when the concentrations of glycine, arginine, $\mathrm{NaHCO}_{3}$ and ascorbic acid were $4.5 \%(\mathrm{~W} / \mathrm{V}), 5.5 \%$ $(\mathrm{W} / \mathrm{V}), \quad 0.8 \% \quad(\mathrm{~W} / \mathrm{V})$ and $2.3 \% \quad(\mathrm{~W} / \mathrm{V})$, respectively. Meanwhile, survival rate of
, then sampling count. The control group and the experimental group are conducted three parallel and calcucate the average value. Finally experimental group survival rate of $B$. bifidum $\mathrm{BB} 01$ is $87.8 \pm 2.3 \%$ after freeze drying, which close to the prediction value $(88.7 \%)$.

lyophilized powder of $B$. bifidum BB01 was significantly improved, which increased by $80.9 \%$ compared with the control group $(6.9 \pm 0.62 \%)$. Experiments confirmed the predicted results, indicating that the optimized conditions and models used were reliable and effective, which can be propose for preservation and application of probiotics powder.

Acknowledgements: This project was supported by Shaanxi Innovation and Transformation Project of Agricultural Science and Technology (No.NYKJ-2015-004) and Shaanxi Innovation and Transformation Project of Agricultural Science and Technology [No.2016KTZDNY02-03].

\section{REFERENCES}

1. Carpenter, J.F. Pikal, M.J. Chang, B.S. \& Randolph, T.W. (1997). Rational design of stable lyophilized protein formulations: some practical advice. Pharmaceutical Biotechnology. 13(8), 109-33. DOI: $10.1023 / \mathrm{a}: 1012180707283$.

2. Champagne, C.P. Detournay, H. \& Hardy, M. J. (1991). Effect of medium on growth and subsequent survival of Lactobacillus delbrueckii subsp.bulgaricus to freeze-drying. Journal of Industrial Microbiology \& Biotechnology. 7(2),147-149. DOI: 10.1007/BF01576077.

3. Chen, H. Wang, J. Luo, Q. \& Shu, G. (2013). Effect of nahco3, mgso4, sodium ascorbate, sodium glutamate, phosphate buffer on survival of lactobacillus bulgaricus during freeze-drying. Advance Journal of Food Science \& Technology, 5(6), 771-774. DOI: 10.19026/ajfst.5.3166.

4. Chen, H. Zhang, J. H. Qin, T. Qi, M. A. \& Shu, G. W. (2014). Effects of sorbitol, mannitol and betaine on the freeze-drying of bifidobacterium bifidum. Food Science \& Technology.

5. Crowe, J. H. Oliver, A. E. \& Tablin, F. (2002). Is there a single biochemical adaptation to anhydrobiosis?. Integrative \& Comparative Biology, 42(3), 497. DOI: 10.1093/icb/42.3.497.

6. Dianawati, D. Mishra, V. \& Shah, N.P. (2013). Survival of Bifidobacterium longum, 1941 microencapsulated with proteins and sugars after freezing and freeze drying. Food Research International. 51(51), 503-509. DOI: 10.1016/j.foodres.2013.01.022. 
7. Fritzenfreire, C.B. Müller, C.M.O. Laurindo, J.B. \& Prudêncio, E.S. (2010). The influence of Bifidobacterium Bb-12 and lactic acid incorporation on the properties of Minas Frescal cheese. Journal of Food Engineering. 96(4), 621-627. DOI: 10.1016/j.jfoodeng.2009.09.010.

8. Iaconelli, C. Lemetais, G. Kechaou, N. Chain, F. Bermúdez-Humarán, L.G. \& Langella, P. (2015). Drying process strongly affects probiotics viability and functionalities. Journal of Biotechnology. 214, 17-26. DOI: 10.1016/j.jbiotec.2015.08.022.

9. Ji, Z.J. \& Guo, D.J. (2008). Optimization of Formula of Protective Additive of Bifidobacterium by Kurtmann, L. Carlsen, C.U. Risbo, J. \& Skibsted, L.H. (2009). Storage stability of freezedried Lactobacillus acidophilus, (La-5) in relation to water activity and presence of oxygen and ascorbate. Cryobiology. 58(2), 175-80. DOI:org/10.1016/j.cryobiol.2008.12.001.

10. Leslie, S.B. Israeli, E. Lighthart, B. Crowe, J.H. \& Crowe, L.M. (1995). Trehalose and sucrose protect both membranes and proteins in intact bacteria during drying. Applied \& Environmental Microbiology. 61(10), 3592-3597.

11. Liu, L. F. \& Meng, X.C. (2006). Damage by freeze-drying and protection of bifidobacterium. China Dairy Industry. 34 (1), 39-43.

12. Ljm, L. Giwde, J. Meerdink, G. \& Kvan,'T.R. (1997). Carbohydrates and the dehydration inactivation of Lactobacillus plantarum: the role of moisture distribution and water activity. Journal of Food Engineering. 31(2), 237-250. DOI: 10.1016/S0260-8774(96)00077-5.

13. Mattern, M. Winter, G. Kohnert, U. \& Lee, G. (1999). Formulation of Proteins in Vacuum-Dried Glasses. II. Process and Storage Stability in Sugar-Free Amino Acid Systems. Pharmaceutical Development \& Technology. 4(2), 199-208. DOI: 10.1081/PDT-100101354.

14. Morgan, C. \& Vesey, G. (2009). Freeze-Drying of Microorganisms. Encyclopedia of Microbiology. 162-173. DOI:org/10.1016/B978-012373944-5.00114-0.

15. Ohtake, S. Schebor, C. Palecek, S.P. \& Pablo, J.J.D. (2004). Effect of sugar-phosphate mixtures on the stability of DPPC membranes in dehydrated systems. Cryobiology. 48(1), 81-89. Ramchandran, L. \& Shah, N.P. (2010). Characterization of functional, biochemical and textural properties of synbiotic low-fat yogurts during refrigerated storage. LWT - Food Science and Technology. 43(5),819-827. DOI: 10.1016/j.lwt.2010.01.012.

16. Ranadheera, R.D.C.S. Baines, S.K. \& Adams, M.C. (2010). Importance of food in probiotic efficacy. Food Research International. 43(1),1-7. DOI:org/10.1016/j.foodres.2009.09.009.

17. Saadatzadeh, A. Fazeli, M.R. Jamalifar, H. \& Dinarvand, R. (2013). Probiotic Properties of Lyophilized Cell Free Extract of Lactobacillus casei. Jundishapur Journal of Natural Pharmaceutical Products. 8(3):131-7.

18. Santivarangkna, C. Kulozik, U. \& Foerst, P.(2007). Alternative Drying Processes for the Industrial Preservation of Lactic Acid Starter Cultures. Biotechnology Progress. 23(2),302-15. DOI: $10.1021 / \mathrm{bp} 060268 \mathrm{f}$.

19. Sun, W. \& Griffiths, M.W. (2000). Survival of bifidobacteria in yogurt and simulated gastric juice following immobilization in gellan-xanthan beads. International Journal of Food Microbiology. 61(1):17-25. DOI: 10.1016/S0168-1605(00)00327-5.

20. Thomas, H. Petra, F. \& Ulrich, K. (2009). Microencapsulation of probiotic cells by means of rennet-gelation of milk proteins. Food Hydrocolloids. 23(7),1670-1677.

21. Tripathi, M.K. \& Giri, S.K.(2014). Probiotic functional foods: Survival of probiotics during processing and storage. Journal of Functional Foods. 9(9),225-241.

22. Wang, W. (2000). Lyophilization and development of solid protein pharmaceuticals. International Journal of Pharmaceutics. 203(1-2),1-60. DOI: 10.1016/S0378-5173(00)00423-3.

23. Weinbreck, F. Bodnar, I. \& Marco, M.L. (2009). Can encapsulation lengthen the shelf-life of probiotic bacteria in dry products? International Journal of Food Microbiology. 136(3),364-7. DOI: 10.1016/j.ijfoodmicro.2009.11.004.

24. WHO, FAO. (2001). Report of a joint FAO/WHO expert consultation on evaluation of health and nutritional properties of probiotics in food including powder milk with live lactic acid bacteria, 1-4 October 2001.(pp.1-34). Amerian Córdoba Park Hotel,Córdoba, Argentina.

25. Yang, C.Y. Zhu, X.L. Fan, D.D. Mi, Y. Luo, Y.E. Hui, J.F. \& Su, R. (2012). Optimizing the Chemical Compositions of Protective Agents for Freeze-drying Bifidobacterium longum BIOMA 5920. Chinese Journal of Chemical Engineering. 20(5), 930-936. DOI:org/10.1016/S10049541(12)60420-0. 